\title{
Characterization of Biological Quality Parameters of Sewage Water in the Sewage Treatment Plants of Madurai Municipal Corporation
}

\author{
J. Prabhaharan ${ }^{1 *}$, R. Uma Sankareshwari ${ }^{2}$, K. Kalaichelvi ${ }^{3}$, \\ N.K. Sathyamoorthy ${ }^{4}$, T. Ragavan ${ }^{1}$ and A. Valliammai ${ }^{5}$ \\ ${ }^{1}$ Coastal Saline Research Centre, Ramanathapuram - 623503 \\ ${ }^{2}$ Department of Agricultural Microbiology, AC \& RI, Madurai- 625104 \\ ${ }^{3}$ Department of Agronomy, AC \& RI, Madurai - 625104 \\ ${ }^{4}$ Department of Agronomy, TNAU, CBE - 641003 \\ ${ }^{5}$ Agricultural Research Station, Bhavanisagar - 638451, India \\ *Corresponding author
}

\begin{tabular}{|l|}
\hline Key w o r d s \\
Dissolved oxygen \\
(DO), BOD, COD \\
and Total coliform \\
population
\end{tabular}

A B S T R A C T

Madurai City Corporation is one among the ten metropolitan cities in Tamil Nadu. Madurai city has two numbers of sewage treatment plants located one at Avaniyapuram and another at Sakkimangalam. This study aimed to characterize biological quality of the sewage water received (raw sewage water and treated sewage water) through Madurai Municipal Corporation. The fallouts of the research revealed that all the parameters of water analysis viz., Dissolved oxygen, Biological Oxygen Demand, Chemical Oxygen Demand, Total coliforms population were observed high in the water samples collected from raw sewage. Compared to raw sewage water samples, treated sewage water samples were observed high dissolved oxygen, low in Biological Oxygen Demand (BOD), low in Chemical Oxygen Demand and total coliform population. All parameters, recorded highest value during the season of summer among other four seasons and lowest value were registered during North - east monsoon season.

\section{Introduction}

India with varied climatic conditions and uneven distribution of water sources enters into the list of water stress countries in the world. In India, the total quantity of water available is assessed as 4200 Billion Cubic
Meter (BCM). The water supply demand for the 498 class I cities is put at 44769 Million Litre per Day (MLD) while the 410 class II towns demand 3324 MLD of water. So, the total drinking water demand for the urban area is 48093 MLD. It indicates the wastewater generation potential and suggests 
the scope for reuse after required treatment for varied applications. Irrigation water quality and quantity have direct and indirect impact on soil characteristics (physical, chemical and biological) and was depend on irrigation, Prabhaharan et al., (2020). Now-adays, various technologies have been developed for the treatment and reclamation of wastewater across the world (CPCB, 2005). Tamil Nadu is the water starving state next to Rajasthan in India. With the $80 \%$ of the geographic area of hard rock, groundwater potential is declining day by day warranting an alternate choice of source for water. In respect of Tamil Nadu, the total population, as per census 2011, is 721.38 lakh (Rural371.89 lakh and Urban - 349.49 lakh).

Madurai City Corporation is one among the ten metropolitan cities in Tamil Nadu. Having located at almost in the center part of the state, it is the city for education and business. City covers an area of 148.99 square kilo meters with a population of 15.64 lakh. Climate prevailing is arid to semi-arid Rainfall is occasional. Annual rainfall varies from $547.0 \mathrm{~mm}$ to $1264.0 \mathrm{~mm}$ against the normal rainfall of $891.50 \mathrm{~mm}$. There are some microbes which can tolerate even high temperature (Uma Sankareshwari and Prabhaharan, 2020). Groundwater table level fluctuation during 1991 to 2012 is found to vary between 4.0 meter and 11.10 meter below ground level. In Madurai district the total geographical area $3742 \mathrm{~km}^{2}$. Madurai city has two numbers of sewage treatment plants located one at Avaniyapuram and another at Sakkimangalam. The former has 125 MLD capacity and the latter's capacity is 47.50 MLD totaling to 172.50 MLD. Hence, the study is taken up to assess waste water generated in Madurai Municipal Corporation and to find out the ways and means of using the waste water for irrigation with the objective of assessing the biological quality of raw and treated sewage water which helps to ascertain waste water potential for supplemental irrigation in Madurai Municipal Corporation and to increase area under irrigation.

\section{Materials and Methods}

Madurai city is located at almost in the southern part of the state, it is the city for education and business. Madurai city has an area of $52 \mathrm{~km}^{2}$ within an urban area now extending over as much as $130 \mathrm{~km}^{2}$ and it is located at $9^{\circ} 56^{\prime} \mathrm{N} 78^{\circ} 07^{\prime} \mathrm{E} / 9^{\circ} .93^{\prime} \mathrm{N} 78^{\circ} .12^{\circ} \mathrm{E}$ (Fig. 1). It has an average elevation of 101 meters above mean sea level. The climate is dry and hot, with Northeast monsoon rains during October-December. Temperatures during summer reach a maximum of 40 and a minimum of $26.3{ }^{\circ} \mathrm{C}$, though temperatures over $43{ }^{\circ} \mathrm{C}$ are not uncommon. Winter temperatures range between 29.6 and $18^{\circ} \mathrm{C}$. The average annual rainfall is about $85 \mathrm{~cm}$. Groundwater table level fluctuation during 1991 to 2012 is found to vary between 4.0 meter and 11.10 meter below ground level. The 2011 census population is 15.64 lakh.

The raw sewage water was collected from inlets of sewage treatment plant (STP) and treated sewage water was collected in clean plastic bottles after necessary treatment from both Avaniapuram and Sakkimanagalam. Concentrated nitric acid $(5 \mathrm{ml})$ was added to the bottle washed because at the time of collection of sample to avoid adsorption of heavy metals on walls of bottle and to preserve it. Samples were also collected without addition of acid in storage bottles. These unacidified samples were used for the estimation of $\mathrm{EC}, \mathrm{pH}$ within two days of sample collection. The raw and treated sewage water analysed for various biological quality parameters viz., dissolved oxygen (DO) by Winkler method, Biological Oxygen Demand (BOD) by Dilution method, Chemical Oxygen Demand (COD) by Open 
reflux method and total coliform population by Bacterial Parameter method as per the reference APHA, 1998.

\section{Results and Discussion}

\section{Biological quality parameters of raw and treated sewage water (Table $1 \& 2$ )}

\section{Dissolved Oxygen (DO)}

The Dissolved oxygen content in water reflects the physical and biological processes prevailing in water and is influenced by aquatic vegetation. The DO content registered always zero in raw sewage water in all the seasons and it was inferred that there was an increment in DO value after the sewage was treated after aerobic process. Low oxygen content in water is usually associated with organic pollution. The zero dissolved oxygen values may also be due to the stagnant and non- flushing conditions of the water with increasing waste load by regular addition of foods and pesticides. The DO value increased from 0 to $3.4 \mathrm{mg} \mathrm{L}^{-1} \& 0$ to $2.91 \mathrm{mg} \mathrm{L}^{-1}$ during SWM season, 0 to $3.8 \mathrm{mg} \mathrm{L}^{-1} \& 0$ to $2.54 \mathrm{mg}$ $\mathrm{L}^{-1}$ during NEM season, 0 to $2.8 \mathrm{mg} \mathrm{L}^{-1} \& 0$ to $3.62 \mathrm{mg} \mathrm{L}^{-1}$ during winter, 0 to $2.4 \mathrm{mg} \mathrm{L}^{-1} \& 0$ to $2.72 \mathrm{mg} \mathrm{L}^{-1}$ during summer and 0 to $3.1 \mathrm{mg}$ $\mathrm{L}^{-1} \& 0$ to $2.95 \mathrm{mg} \mathrm{L}^{-1}$ in the average values in raw and treated sewage water in Sakkimangalam and Avaniapuram STPs respectively. On contrast to the low Dissolved Oxygen content in raw sewage water, the treated sewage water DO level was recorded high. Similar results reported by Rajendran et al., (2014); Chawala et al., (2001). It is gradually increased by the aerobic process which was carried out in treating raw sewage water. Very low DO content showed the presence of high organic matter which leads to the consumption of oxygen during its decomposition carried out by the heterotrophs in water, (Mishra and Tripathi, 2001).

\section{Biological Oxygen Demand (BOD)}

The BOD is an indication of the organic load of sewage waste water. The BOD of the sewage is the amount of oxygen required for the biochemical decomposition of biodegradable organic matter under aerobic conditions. The oxygen consumed in the process is related to the amount of decomposable organic matter. Usually the microorganisms require more oxygen to reduce the organic nutrient present in sewage waste water. The BOD content was reduced from 260 to $8 \mathrm{mg} \mathrm{L}^{-1} \& 252$ to $9.0 \mathrm{mg} \mathrm{L}^{-1}$ in SWM season, 230 to $10 \mathrm{mg} \mathrm{L}^{-1} \& 315$ to 7.0 $\mathrm{mg} \mathrm{L}^{-1}$ during NEM season, 280 to $9 \mathrm{mg} \mathrm{L}^{-1}$ \& 224 to $11.0 \mathrm{mg} \mathrm{L}^{-1}$ during winter, 310 to 7 $\mathrm{mg} \mathrm{L}^{-1} \& 286$ to $9.0 \mathrm{mg} \mathrm{L}^{-1}$ during summer and the mean value were also reduced from 270 to $8.5 \mathrm{mg} \mathrm{L}^{-1}$ \& 269 to $9.0 \mathrm{mg} \mathrm{L}^{-1}$ in RSW and TSW in Sakkimangalam and Avaniapuram STPs respectively. The effect of dissolve oxygen content was reflected on BOD of water samples. Among the four seasons, summer season was recorded high BOD level. The general range of BOD observed for raw sewage is 100 to $400 \mathrm{mg}$ $\mathrm{L}^{-1}$. As the BOD gives a quantitative index of the degradable organic substances in water and a measure of waste strength, higher BOD content had negative correlation as its usage i.e. the lower value is recommended for use, CPCB (2000). Gradual decline of BOD from monsoon followed by summer was attributed to decrease in temperature which in turn retards microbial activity. High concentration of organic matter in sewage water is reflected by its high BOD values, (FAO, 1985).

\section{Chemical Oxygen Demand (COD)}

The COD gives the measure of the oxygen required for chemical oxidation. It does not differentiate between biological oxidisable and non-oxidisable material. The COD values of sewage water were quite above the ISI 
standard limit of $500 \mathrm{mg} \mathrm{L}^{-1}$. The highest COD content was noticed during summer (504 \& $\left.517 \mathrm{mg} \mathrm{L}^{-1}\right)$ which was followed by winter $\left(480 \mathrm{mg} \mathrm{L}^{-1}\right)$ in Sakkimangalam and in SWM (484 mg L ${ }^{-1}$ ) in Avaniapuram. The NEM season recorded the lowest COD of 442 $\mathrm{mg} \mathrm{L}^{-1}$ in Sakkimangalam and in winter (441 $\mathrm{mg} \mathrm{L}{ }^{-1}$ ) in Avaniapuram. The mean value of the COD content was recorded as $471.7 \&$ $475 \mathrm{mg} \mathrm{L}^{-1}$ in raw sewage water and the COD content in treated sewage water ranged from 55 - $96 \& 54-94 \mathrm{mg} \mathrm{L}^{-1}$ with a mean value $74.3 \& 73.8 \mathrm{mg} \mathrm{L}^{-1}$ in Sakkimangalam and Avaniapuram STPs respectively. The COD content was drastically reduced in the sewage water after its treatment. Jena et al., (2010) recorded similar type of results. On the basis of BOD and COD, the raw sewage water was rated as unsuitable for irrigation purpose as it crossed the prescribed limits of 100 and 250 $\mathrm{mg} \mathrm{L}^{-1}$ for BOD and COD, respectively (Yadav et al., 2002). The higher values of COD might be due to the presence of chemically oxidisable organic matter present therein. The COD exhibited very high amounts in the raw sewage but soon after the treatment viz., sequential Batch Reactor Technology it was reduced $<75$ for COD) considerably and was well within the limit.

Fig.1 Location of Madurai district

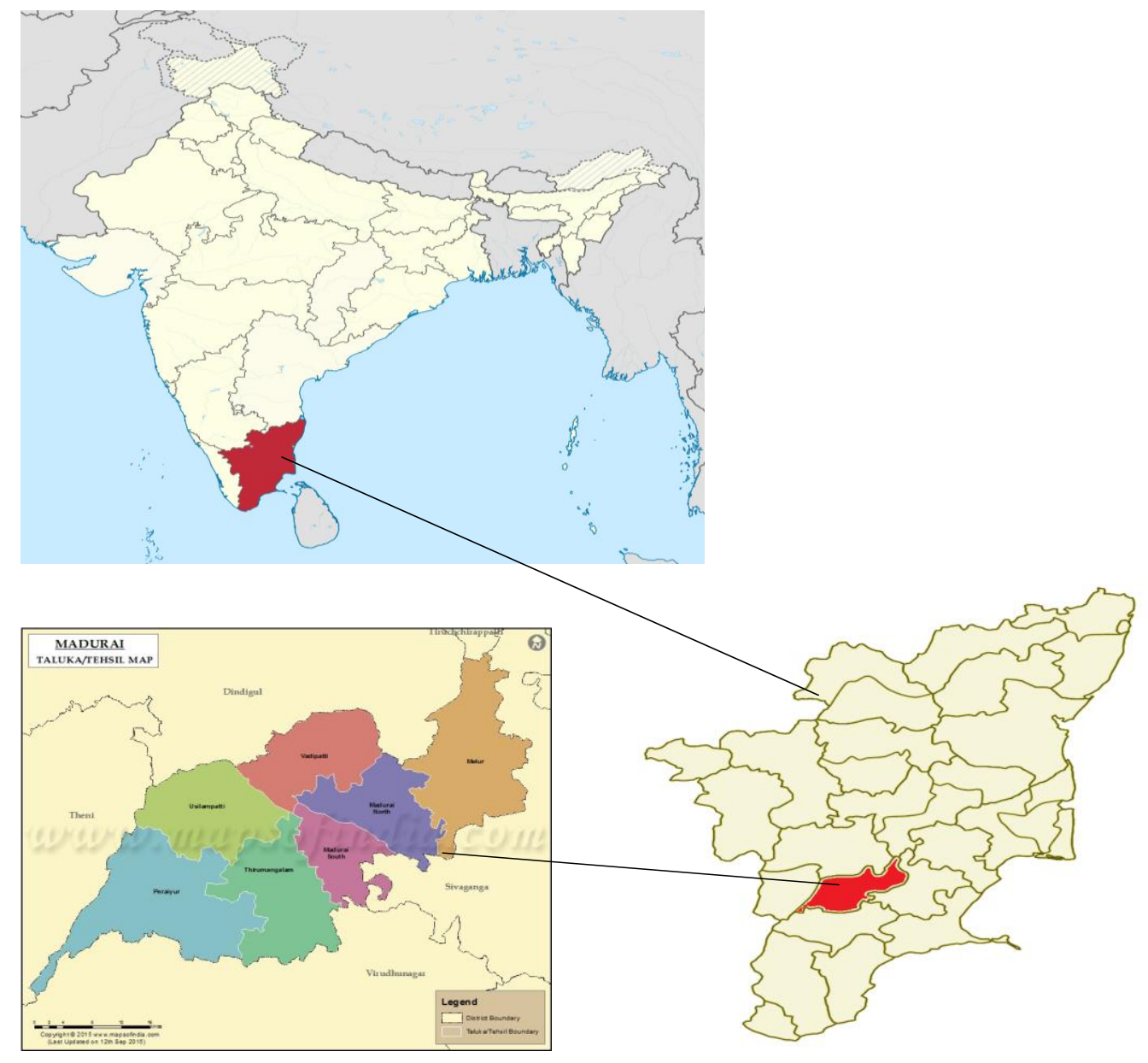


Table.1 Biological characteristics raw and treated sewage water in STP, Sakkimangalam

\begin{tabular}{|c|c|c|c|c|c|c|c|c|c|}
\hline \multirow[t]{2}{*}{ S.No } & \multirow[t]{2}{*}{ Seasons } & \multicolumn{2}{|c|}{$\begin{array}{c}\text { DO } \\
\left(\mathrm{mg} \mathrm{L}^{-1}\right)\end{array}$} & \multicolumn{2}{|c|}{$\underset{\left(\mathrm{mg} \mathrm{L}^{-1}\right)}{\text { BOD }}$} & \multicolumn{2}{|c|}{$\underset{\left(\mathrm{mg} \mathrm{L}^{-1}\right)}{\mathrm{COD}}$} & \multicolumn{2}{|c|}{$\begin{array}{l}\text { Total Coliforms } \\
\text { (MPN/100ml) }\end{array}$} \\
\hline & & RSW & TSW & RSW & TSW & RSW & TSW & RSW & TSW \\
\hline 1. & $\begin{array}{c}\text { South West } \\
\text { Monsoon } \\
\text { (June-Sep) }\end{array}$ & 0 & 3.40 & 260 & 8 & 458 & 64 & 27 & 9.0 \\
\hline 2. & $\begin{array}{l}\text { North East } \\
\text { Monsoon } \\
\text { (Oct- Dec) }\end{array}$ & 0 & 3.80 & 230 & 10 & 442 & 55 & 34 & 12.0 \\
\hline 3. & $\begin{array}{l}\text { Winter } \\
\text { (Jan-Feb) }\end{array}$ & 0 & 2.80 & 280 & 9 & 480 & 80 & 11 & 6.0 \\
\hline 4. & $\begin{array}{c}\text { Summer } \\
\text { (Mar-May) }\end{array}$ & 0 & 2.40 & 310 & 7 & 504 & 96 & 7 & 2.0 \\
\hline \multicolumn{10}{|c|}{ Range } \\
\hline & Minimum & 0.0 & 2.4 & 230.0 & 7.0 & 442 & 55 & 7.0 & 2.0 \\
\hline & Maximum & 0.0 & 3.8 & 310.0 & 10.0 & 504 & 96 & 34.0 & 12.0 \\
\hline & Mean & 0.0 & 3.1 & 270.0 & 8.5 & 471.7 & 74.3 & 19.8 & 7.3 \\
\hline & SD & 0.0 & 0.6 & 33.7 & 1.3 & 27.0 & 18.1 & 12.8 & 4.3 \\
\hline
\end{tabular}

Table.2 Biological characteristics raw and treated sewage water in STP, Avaniyapuram

\begin{tabular}{|c|c|c|c|c|c|c|c|c|c|}
\hline \multirow[t]{2}{*}{ S.No } & \multirow[t]{2}{*}{ Seasons } & \multicolumn{2}{|c|}{$\begin{array}{c}\text { DO } \\
(\mathrm{mg} / \mathrm{l})\end{array}$} & \multicolumn{2}{|c|}{ BOD (mg/l) } & \multicolumn{2}{|c|}{ COD (mg/l) } & \multicolumn{2}{|c|}{$\begin{array}{l}\text { Total Coliforms } \\
\text { (MPN/100ml) }\end{array}$} \\
\hline & & RSW & TSW & RSW & TSW & RSW & TSW & RSW & TSW \\
\hline 1. & $\begin{array}{c}\text { South West } \\
\text { Monsoon (June- } \\
\text { Sep) }\end{array}$ & 0 & 2.91 & 252 & 9.0 & 484 & 79.1 & 39 & 19.0 \\
\hline 2. & $\begin{array}{l}\text { North East } \\
\text { Monsoon } \\
\text { (Oct- Dec) }\end{array}$ & 0 & 2.54 & 315 & 7.0 & 458 & 54.0 & 28 & 12.0 \\
\hline 3. & $\begin{array}{c}\text { Winter } \\
\text { (Jan-Feb) }\end{array}$ & 0 & 3.62 & 224 & 11.0 & 441 & 68.2 & 16 & 8.0 \\
\hline 4. & $\begin{array}{c}\text { Summer } \\
\text { (Mar-May) }\end{array}$ & 0 & 2.72 & 286 & 9.0 & 517 & 94.0 & 9 & 2.0 \\
\hline \multicolumn{10}{|c|}{ Range } \\
\hline & Minimum & 0 & 2.54 & 224 & 7.0 & 441 & 54.0 & 9 & 2.0 \\
\hline & Maximum & 0 & 3.62 & 315 & 11.0 & 517 & 94.0 & 39 & 19.0 \\
\hline & Mean & 0 & 2.95 & 269 & 9.0 & 475 & 73.8 & 23 & 10.2 \\
\hline & SD & 0 & 0.37 & 41.0 & 1.24 & 20.8 & 11.2 & 9.7 & 2.9 \\
\hline
\end{tabular}




\section{Total coliforms}

The total coliform content decreased from raw to treated sewage water in SWM, NEM, winter and summer seasons viz., 27 to $9 \& 39$ to $19 \mathrm{MPN} / 100 \mathrm{ml}, 34$ to $12 \& 28$ to 12 MPN/100 ml, 11 to $6 \& 16$ to $8 \mathrm{MPN} / 100 \mathrm{ml}$ and 7 to $2 \& 9$ to $2 \mathrm{MPN} / 100 \mathrm{ml}$ respectively. The mean total coliform level of raw sewage was $19.8 \& 23.0 \mathrm{MPN} / 100 \mathrm{ml}$ and treated sewage water was $7.3 \& 10.2 \mathrm{MPN} / 100 \mathrm{ml}$. The total coliform level is high in pre treatment sample and it has been reduced to half to one third by very many processes.

The total coliforms present in raw sewage has showed maximum value might be due to the suspended organic material added to soil through sewage which serves as a source of energy for microbial population.

Higher temperature in the summer seasons perhaps arrest the growth of microorganisms present in the sewage water. However, it was interesting to note a high count of actinomycetes even during the summer. Anandavalli (1986) also reported higher total coliform counts (up to $1 \times 10^{7} \mathrm{MPN} / 100 \mathrm{ml}$ ) in some wells of Madurai city which had an open drainage nearby.

In conclusion, the fallouts of the research revealed that all the parameters of water analysis viz., Dissolved oxygen, Biological Oxygen Demand, Chemical Oxygen Demand, Total coliforms population were observed high in the water samples collected from raw sewage whereas in treated sewage water samples were observed low in Biological Oxygen Demand (BOD), low in Chemical Oxygen Demand and total coliform population. Hence it is suggested that this treated sewage water can be used as irrigation for fodders and other high water and nutrient requiring crops.

\section{References}

Anandavalli, A. 1986. Water pollution in Madurai: Yesterday, Publication Division, Madurai Kamaraj University, Madurai, p. 192.

APHA. 1998. Standard Methods for the Examination of Water and Wastewater. American Public

Health Association/American Water Works Association/Water Environment Federation, 20th edn, Washington DC, USA.

CPCB. 2005. Performance Status of Common Effluent Treatment Plants in India. Central Pollution Control Board, India.

CPCB. 2000. Parivesh Sewage Pollution News Letter. Central Pollution Control Board, Ministry of Environment and Forests, Govt. of India, Parivesh Bhawan, East Arjun Nagar, Delhi.110032.

Chawala, J.K., S.D. Khepar, M. Siag and Dinesh Kumar. 2001. Quality status and optimum utilization of village pond water, a case study. Indian J. Environ. Hlth., 43(3):114-118.

FAO. 1985. Water quality for agriculture. R.S. Ayers. and D.W. Westcot. FAO Irrigation and Drainage Paper 29, Rev. 1. FAO, Rome. p.17.

Jena, D., A.K. Dash, R.Y. Erra, B. Mohanty, B. Jena and S.K. Mukthi. 2010. Effect of continuous use of sewage water on soil properties and plants. Asian. J. Soil Sci., 4(2): 158-164.

Mishra, M. and V. Tripathi. 2001. Impacts of city sewage discharge in physicochemical characterizes of Ganga River. Asian J. Microbiol. Biotech. Env. Sci., 3(4): 333-338.

Prabhaharan, J., K.Kalaichelvi, N.K. Sathyamoorthy, T. Ragavan and Valliammai, A. 2020. Assessment of Irrigation Water Quality (Ground Water) of Melur Block, Madurai 
District, Tamil Nadu. International Journal of Chemical studies 2020: 8(4):979-982

Rajendran, S.M. and V. Sekaran. 2014. Municipal wastewater reuse in arid regions - scope for irrigation in Madurai City. Intern. J. Civil Engee. Tech., 5(7): 64-80.

Uma Sankareshwari, R. and Prabhaharan, J. 2020. Molecular level stress response in
Rhizobia Identification of Heat Shock Proteins International Journal of Current Microbiology and Applied Sciences (2020). 9 (8) 3385- 3396

Yadav, R.K., B. Goyal, R.K. Sharma, S.K. Dubey and P.S. Minhas. 2002. Postirrigation impact of domestic sewage effluent on composition of soils, crops and ground water - A case study Environment International. 28: 481-486.

\section{How to cite this article:}

Prabhaharan, J., R. Uma Sankareshwari, K. Kalaichelvi, N.K. Sathyamoorthy, T. Ragavan and Valliammai, A. 2020. Characterisation of Biological Quality Parameters of Sewage Water in the Sewage Treatment Plants of Madurai Municipal Corporation. Int.J.Curr.Microbiol.App.Sci. 9(11): 1951-1957. doi: https://doi.org/10.20546/ijcmas.2020.911.231 